\title{
PEMANFAATAN LUBUK LARANGAN UNTUK MENINGKATKAN KESEHJATERAAN MASYARAKAT DI DESA ANGGOLI KECAMATAN SIBABANGUN KABUPATEN TAPANULI TENGAH
}

\author{
Nora Yanti Simbolon ${ }^{1)}$, Effan Zulfiqar²), Darman Syah Pulungan³) \\ Univeristas Muhammadiyah Tapanuli Selatan \\ norayanti.simbolon@um-tapsel.ac.id ${ }^{1)}$ \\ effan.zulfiqar@um-tapsel.ac.id ${ }^{2)}$ \\ darmansyah.pulungan@um-tapsel.ac.id ${ }^{3)}$
}

\begin{abstract}
Abstrak
Program lubuk larangan BUMDes Sepakat ini dilakukan di Desa Anggoli karena daerah aliran sungai yang luas sehingga pemerintah desa dan masyarakat berinisiatif untuk mengembangkan daerah aliran sungai menjadi sumber pendapatan asli desa yang bermanfaat bagi masyarakat terkhususnya bagi anak yatim piatu,orangtua jompo,dan membangun sarana dan prasarana desa. Tujuan penelitian ini adalah untuk mengetahui bagaimana pemanfaatan lubuk larangan di Desa Anggoli Kecamatan Sibabangun Kabupaten Tapanuli Tengah, untuk mengetahui bagaimana tingkat kesehjateraan masyarakat dalam meningkatkan taraf hidup masyarakat melalui lubuk larangan di Desa Anggoli Kecamatan Sibabangun Kabupaten Tapanuli Tengah, untuk mengetahui seberapa besar pengaruh pemanfaatan lubuk larangan terhadap kesehjateraan masyarakat di Desa Anggoli Kecamatan Sibabangun Kabupaten Tapanuli Tengah. Berdasarkan hasil analisis yang telah dilakukan maka, diperoleh nilai kolerasi sebesar 0,684 sedangkan nilai kolerasi dalam tabel kolerasi untuk $n=72$ dan taraf signifikan $5 \%$ diperoleh nilai sebesar 0,235 , berarti $r_{\text {hitung }}$ yaitu 0,684 lebih besar dari nilai $r_{\text {tabel }}$ kolerasi yaitu 0,235 . Dengan demikian hipotesis yang dirumuskan dalam penelitian ini dapat diterima, yang berarti ada pengaruh yang signifikan atau positif dari pemanfaatan lubuk larangan untuk meningkatkan kesehjateraan masyarakat di Desa Anggoli Kecamatan Sibabangun Kabupaten Tapanuli Tengah.
\end{abstract}

Kata kunci: pemanfaatan, lubuk larangan, kesehjateraan.

\begin{abstract}
This BUMDes Sepakat ban program was conducted in Anggoli Village because of the extensive watershed so that the village government and the community took the initiative to develop the watershed to be a source of original village income that was beneficial to the community especially for orphans, elderly people, and building facilities and infrastructure village. The purpose of this study was to find out how to use the lubuk ban in Anggoli Village, Sibabangun Subdistrict, Central Tapanuli Regency, to find out how the level of community welfare in improving the standard of living of the people through the lubuk ban in Anggoli Village, Sibabangun Subdistrict, Tapanuli Tengah Regency, to find out how much influence the use of the ban lubuk on community health in Anggoli Village, Sibabangun District, Central Tapanuli Regency. Based on the results of the analysis that has been carried out, a correlation value of 0.684 is obtained while the correlation value in the correlation table for $n$ $=72$ and a significant level of $5 \%$ is obtained a value of 0.235 , meaning the rcount is 0.684 greater than the value of the correlation table that is 0.235 . Thus the hypothesis formulated in this study can be accepted, which means that there is a significant or positive influence from the use of a lubuk ban to improve community health in Anggoli Village, Sibabangun District, Central Tapanuli Regency.
\end{abstract}

Keywords: utilization, the depth of the prohibition, welfare. 


\section{PENDAHULUAN}

Dalam UUD 1945 BAB XIV tentang Kesehjateraan Sosial pasal 33 yang berbunyi sebagai berikut:

Tercantum dasar demokrasi, ekonomi, produksi dikerjakan oleh semua, untuk semua dibawah pimpinan atau pemilikan anggota-anggota masyarakat.

Kemakmuran masyarakatlah yang di utamakan, bukan kemakmuran orang seorang. Sebab itu perekonomian disusun sebagai usaha bersama berdasar atas asas kekeluargaan. Bangun perusahaan yang sesuai dengan itu ialah koperasi. Perekonomian berdasar atas demokrasi ekonomi, kemakmuran bagi semua orang sebab itu cabang cabang produksi yang penting bagi negara, bumi dan air dan kekayaan alam yang terkandung dalam bumi adalah pokok-pokok kemakmuran rakyat sebab itu harus dikuasai oleh Negara dan dipergunakan untuk sebesar-besar kemakmuran rakyat. (Undang-Undang Dasar Negara Republik Indonesia 1945, Sekretariat Jendral MPR RI Tahun 2014).

Pemanfaatan sumber daya alam sungai merupakan salah satu unsur yang sangat penting untuk berkelanjutan kehidupan makhluk hidup terutama masyarakat, kehidupan masyarakat yang berada di sekitar sungai bergantung pada sumber daya alam, penggunaan sumber daya alam tergantung pada pengetahuan dan kemampuan masyarakat dalam memelihara sumber daya sungai, keberadaan sungai bagi masyarakat desa sebagai penghidupan lahan pertanian dan perikanan dengan adanya pengelolaan sumber daya alam sungai keberadaannya tetap bermanfaat dan berkelanjutan untuk kepentingan jangka panjang masyarakat, pengelolaan sumber daya alam sungai yang berada di lingkungan masyarakat mempengaruhi aktivitas masyarakat dalam menjaga dan melindungi daerah aliran sungai. Salah satu cara pemanfaatan sumber daya alam (SDA) adalah daerah aliran sungai yang ada di sekitar alam lingkungan yang dimanfaatkan untuk berbagai kepentingan dan kebutuhan hidup masyarakat.

Menurut Peraturan Pemerintah Nomor 38 Tahun 2011 Tentang Sungai di jelaskan dalam pasal 30 ayat (2) dan (3) pasal 31 dan pasal 32 menyatakan bahwa:

Ayat 2 yaitu:

Pemanfaatan sungai sebagaimana dimaksud pada ayat (1) meliputi pemanfaatan untuk:

a. Rumah tangga

b. Pertanian

c. Sanitasi lingkungan

d. Industri

e. Pariwisata

f. Olahraga

g. Pertahanan

h. Perikanan

i. Pembangkit tenaga listrik

j. Transportasi

Ayat 3 yaitu:

(1) pengembangan sungai sebagaimana dimaksud pada ayat (1) dilakukan dengan tidak merusak ekosistem sungai, mempertimbangkan karakteristik sungai,kelestarian keanekaragaman hayati, serta kekhasan dan aspirasi daerah atau masyarakat setempat.

Pasal 31 yaitu:

(1) Pemanfaatan sungai sebagaimana dimaksud dalam pasal 30 ayat (1) dilakukan dengan ketentuan:

a. Mengutamakan pemenuhan kebutuhan pokok sehari-hari dan pertanian rakyat dan sistem irigasi yang sudah ada; dan

b. Mengalokasikan kebutuhan air untuk aliran pemeliharaan sungai

Pasal 32 yaitu:

Dalam melakukan pemanfaatan sungai untuk perikanan sebagaimana dimaksud dalam pasal 30 ayat (2) huruf $h$, selain harus mengikuti ketentuan sebagaimana dimaksud dalam pasal 31 , harus pula mempertimbangkan daya tamping dan daya dukung lingkungan sungai.

Pengelolaan sumber daya air sungai dimanfaatkan menjadi lahan perikanan yang biasa disebut di desa sebagai lubuk larangan, wilayah aliran sungai tersebut sebagai wilayah yang terlarang untuk di ambil ikannya selama jangka waktu 
tertentu, maka dari pengelolaan sumber daya air sungai pemerintah desa memiliki program pemanfaatan lubuk larangan di daerah aliran sungai (DAS) yang dimanfaatkan masyarakat sekitar untuk pengelolaan tangkapan ikan di daerah aliran sungai, secara teratur menurut hukum yang dimusyawarakan masyarakat sekitar, baik itu batas-batas lubuk larangannya, pelanggaran atas aturan serta masa pembukaan lubuk larangan. Lubuk larangan merupakan salah satu kearifan lokal yang dikelola secara bersama dan mempunyai badan hukum dan aturan yang disepakati masyarakat secara bersama oleh pihak pemerintah desa dan menjadi budaya kearifan lokal yang tetap terjaga kelestarian lingkungan di sepanjang sungai.

$$
\text { Biaya pengelolaan program }
$$

pemanfaatan lubuk larangan ini melalui program dana desa, yang di atur secara khusus dalam Peraturan Pemerintah Republik Indonesia Nomor 60 Tahun 2014 Tentang Dana Desa yang Bersumber dari Anggaran Pendapatan dan Belanja Negara pasal (2) bahwa:

Dana desa adalah dana yang bersumber dari anggaran pendapatan dan belanja negara yang diperuntunkan bagi desa yang ditransfer melalui anggaran pendapatan dan belanja daerah kabupaten/kota dan digunakan untuk membiayai penyelenggaraan pemerintahan, pelaksanaan pembangunan, pembinaan kemasyarakatan, dan pemberdayaan masyarakat.

Dalam UU Nomor 6 Tahun 2014 tentang Desa, "yaitu adanya komitmen negara dalam melindungi dan memberdayakan desa agar lebih menjadi kuat, maju, mandiri dan demokratis sehingga dapat menciptakan landasan yang kuat dalam melaksanakan pemerintahan dan pembangunan menuju masyarakat yang adil, makmur dan sejahtera."(Undang-Undang Nomor 6 Tahun 2014 Tentang Desa)

Lubuk larangan yang berada di Desa Anggoli diberi nama "lubuk larangan Sepakat" yang mengelola lubuk larangan Sepakat merupakan Badan Usaha Milik
Desa Anggoli sesuai dengan nama kelompok BUMDes di Desa Anggoli, Sepakat merupakan sebuah nama yang dibentuk pemerintah Desa Anggoli dan masyarakat untuk mengawasi jalannya lubuk larangan, pembentukan lubuk larangan melalui sebuah musyawarah warga yang terdiri dari berbagai unsur masyarakat diantaranya pemerintah Desa Anggoli, pengurus BUMDes Desa Anggoli, dan masyarakat Desa Anggoli. Berdasarkan uraian-uraian sebelumnya dapat disimpulkan bahwa sungai bagi masyarakat Desa Anggoli tidak hanya sebagai sarana perekonomian, namun sungaipun tempat kegiatan sosial bagi sebagian masyarakat Desa Anggoli sungai digunakan untuk keperluan mandi dan mencuci, sehingga di sungai Anggoli merupakan tempat kegiatan sosial dimana anggota masyarakat terutama ibu-ibu saling berinteraksi dan anak-anak bermain dan berenang sambil tertawa riang, tetapi terdapat sejumlah masyarakat yang tidak melindungi daerah aliran sungai Anggoli dan membuang sampah sembarangan langsung ke sungai sehingga menyebabkan sungai kotor seperti masyarakat yang tinggal di pinggiran sungai yang sering membuang sampah langsung ke sungai Anggoli.

Hasil dari lubuk larangan Sepakat Desa Anggoli dibuat untuk meningkatkan kesehjateraan masyarakat untuk memenuhi taraf hidup yang saling berkaitan dengan adanya peningkatan taraf hidup melalui pembukaan lubuk larangan yang diberikan kepada anak yatim dan orang tua jompo yang sangat membantu pendapatan setelah adanya program pemanfaatan lubuk larangan tersebut, sehingga taraf hidup masyarakat terpenuhi dan sangat membantu masyarakat di Desa Anggoli,untuk memenuhi kebutuhan bagi masyarakatuntuk meningkatkan kebutuhan melalui pemanfaatan lubuk larangan untuk kepentingan masyarakat Desa Anggoli contohnya: anak yatim, orang tua jompo, membangun masjid, membangun madrasah, membangun sarana dan prasarana desa, pengadaan alat serikat tolong menolong (STM) dibidang kematian, pernikahan. 
Berdasarkan hasil wawancara dengan kepala Desa Anggoli di simpulkan bahwa penaburan ikan di daerah aliran sungai anggoli yang merupakan lubuk larangan dengan keseluruhan sebanyak 7.580 ikan, terdiri dari ikan nila sebanyak 3.800 ikan Mas sebanyak 3.780. Setiap pembukaan lubuk larangan Sepakat Desa Anggoli dilakukan dua kali dalam setahun dan ada juga sekali dalam setahun. Hasil keuntungan yang diperoleh setiap tahunnya kurang lebih Rp. 30.000 .000 , bagi pelaku yang mengambil ikan di area lubuk larangan Sepakat Desa Anggoli akan diberi sanksi yaitu pelaku akan dikenai denda sebanyak Rp. 1,5 juta.

Identifikasi Masalah

Berdasarkan latar belakang di atas dapat diidentifikasi bahwa masalah utama yang muncul dalam penelitian ini adalah

1. Kurangnya kesadaran masyarakat yang tidak melindungi daerah aliran sungai dan membuang sampah sembarangan langsung ke sungai sehingga menyebabkan sungai kotor misalnya masyarakat yang tinggal di pinggiran sungai yang sering membuang sampah langsung ke sungai.

2. Pembagian pemanfaatan lubuk larangan untuk meningkatkan kesehjateraan masyarakat yang sangat membantu dalam meningkatkan kebutuhan dan kepentingan masyarakat Desa Anggoli contohnya: kepada anak yatim, orang tua jompo, membangun masjid, membangun madrasah, membangun sarana dan prasarana desa, pengadaan alat serikat tolong menolong (stm) dibidang kematian, pernikahan di Desa Anggoli Kecamatan Sibabangun Kabupaten Tapanuli Tengah.

3. Memanfaatkan kembali sumber daya ikan dan pembelian bibit ikan untuk pemamfaatan lubuk larangan.

\section{Pembatasan Masalah}

Untuk memberikan gambaran yang jelas dalam menentukan ruang lingkup penelitian serta lebih terarahnya masalah masalah yang akan di teliti maka penulis membatasi masalah hanya pada jenis pemanfaatan hasil lubuk larangan untuk meningkatkat kesehjateraan masyarakat untuk meningkatkan taraf hidup anak yatim dan orang tua jompo di Desa Anggoli Kecamatan Sibabangun Kabupaten Tapanuli Tengah.

\section{Tujuan Penelitian}

Tujuan penulis mengadakan penelitian ini adalah sebagai berikut:

1. Untuk mengetahui bagaimana pemanfaatan lubuk larangan di Desa Anggoli Kecamatan Sibabangun Kabupaten Tapanuli Tengah.

2. Untuk mengetahui bagaimana tingkat kesehjateraan masyarakat dalam meningkatkan taraf hidup masyarakat melalui lubuk larangan di Desa Anggoli Kecamatan Sibabangun Kabupaten Tapanuli Tengah.

3. Untuk mengetahui seberapa besar pengaruh pemanfaatan lubuk larangan terhadap kesehjateraan masyarakat di Desa Anggoli Kecamatan Sibabangun Kabupaten Tapanuli Tengah

\section{METODE PENELITIAN}

Penelitian ini dilakukan di Desa Anggoli Kecamatan Sibabangun Kabupaten Tapanuli Tengah yang terletak di Kawasan Barat Pulau Sumatera, dengan wilayah sebagian merupakan pulau-pulau kecil di Samudera Hindia. Ibukota Kabupaten Tapanuli Tengah adalah Pandan. Kabupaten Tapanuli Tengah terdiri atas 20 (dua puluh) kecamatan, 30 (tiga puluh) Kelurahan dan 147 (seratus empat puluh tujuh) desa. Penduduk Tapanuli Tengah terdiri atas multi etnik yaitu suku Pesisir, Batak, Minang, Jawa - Madura, Bugis, Cina, Aceh, Melayu, Sunda, dan lain-lain, dengan mayoritas suku Batak. Pelestarian nilai-nilai luhur dan kebangsaan, kerukunan, keamanan, ketertiban dan toleransi dalam semangat gotong-royong yang terjalin dan terbina selama ini semakin kondusif dan tangguh secara sosial kemasyarakatan terus dibina dan ditingkatkan dalam rangka meningkatkan kesadaran, disiplin, kepedulian dan semangat kebersamaan seluruh lapisan masyarakat dengan semangat Sahata Saoloan (Seiya Sekata) untuk memperkokoh semangat Bhineka Tunggal Ika. 


\section{Letak dan Luas Desa Anggoli}

Lokasi penelitian berada di Desa Anggoli. Desa ini mempunyai luas wilayah 6,02 $\mathrm{Ha}$. Desa ini tidak jauh dari pusat pasar Kecamatan Sibabangun dengan perkiraan jarak 15 menit menuju pasar dengan menggunakan jalur becak,motor. Desa Anggoli berada di pinggir jalan raya lintas Sibolga Sidimpuan perbatasan antara Tapanuli Tengah dan Tapanuli Selatan, jalur masuk kedalam perkampungan ini ialah dengan menggunakan jalur darat ataupun transportasi motor.

Dalam penentuan wilayah Desa Anggoli pasti ada perkiraan-perkiraan tertentu, daerah ini memiliki batas-batas Desa Anggoli sebagai berikut:

1) Sebelah Barat berbatasan dengan Desa Sibabangun

2) Sebelah Timur berbatasan dengan Desa Garoga

3) Sebelah Selatan berbatasan dengan Desa Mombang Boru

4) Sebelah Utara berbatasan dengan Desa Muara Sibintuon

\section{Monografi Penduduk}

Penduduk Desa Anggoli Kecamatan Sibabangun Kabupaten Tapanuli Tengah terdapat 725 kepala Keluarga (KK), yang jumlah keseluruhan masyarakat adalah 2.900 orang (jiwa), untuk lebih jelasnya dapat dilihat pada tabel berikut:

\begin{tabular}{|c|l|c|}
\hline No & Jenis Kelamin & Jumlah (jiwa) \\
\hline 1 & Laki- laki & 1.300 \\
\hline 2 & Perempuan & 1.600 \\
\hline \multicolumn{2}{|c|}{ Jumlah } & 2.900 \\
\hline
\end{tabular}

Sumber: Kantor Kepala Desa Anggoli Tahun 2019

Berdasarkan tabel di atas dapat disimpulkan bahwa jenis kelamin perempuan (1.600) lebih banyak dari lakilaki (1.300) dengan penduduk sebanyak 2.900 .

Komposisi penduduk menurut umur dapat dilihat pada tabel 3.2 berikut:

\begin{tabular}{|c|c|c|c|c|}
\hline \multirow[b]{2}{*}{ No } & \multirow{2}{*}{$\begin{array}{c}\text { Golongan } \\
\text { umur } \\
\text { (Tahun) }\end{array}$} & \multicolumn{2}{|c|}{ Jenis kelamin (jiwa) } & \multirow[b]{2}{*}{ Jumlah } \\
\hline & & $\begin{array}{l}\text { Laki- } \\
\text { laki }\end{array}$ & Perempuan & \\
\hline 1 & $0-15$ & 395 & 480 & 875 \\
\hline 2 & $16-55$ & 692 & 788 & 1480 \\
\hline
\end{tabular}

\begin{tabular}{|r|r|r|r|r|}
\hline 3 & $>55$ & 220 & 325 & 545 \\
\hline \multicolumn{2}{|c|}{ Jumlah } & 1593 & 1307 & 2900 \\
\hline
\end{tabular}

Sumber: Kantor Kepala Desa Anggoli 2019

Komposisi penduduk menurut tingkat pendidikan dapat dilihat pada tabel 3.4 berikut:

\begin{tabular}{|c|l|c|}
\hline No & Lulusan Pendidikan & Jumlah (Jiwa) \\
\hline 1 & PAUD & - \\
\hline 2 & Taman Kanak-Kanak & 169 \\
\hline 3 & Sekolah Dasar & 408 \\
\hline 4 & SMP/SLTP & 625 \\
\hline 5 & SMA/SLTA & 710 \\
\hline 6 & AKADEMI/D3-S1-S2 & 98 \\
\hline 7 & $\begin{array}{l}\text { Tidak Tamat Sekolah } \\
\text { Dasar }\end{array}$ & 890 \\
\hline \multicolumn{2}{|l|}{ Jumlah } & 2900 \\
\hline
\end{tabular}

Sumber: Kantor Kepala Desa Anggoli 2019

\section{Gambaran Umum Lubuk Larangan Sepakat Desa Anggoli Kecamatan Sibabangun Kabupaten Tapanuli Tengah}

Lubuk larangan Sepakat yang berada di perbatasan Tapanuli Selatan dan Tapanuli Tengah secara administrasi berada di wilayah Pemerintahan Desa Anggoli berada di Kecamatan Sibabangun Kabupaten Tapanuli Tengah. Lubuk larangan Sepakat memiliki panjang $2 \mathrm{~km}$ dan lebarnya 10-15 meter. Pemerintah desa dan masyarakat memanfaatkannya untuk menjaga kelestarian sumber daya untuk melarang mengambil ikan kecuali pada pembukaan lubuk larangan.

Lubuk larangan Sepakat merupakan program yang dibuat dari BUMDes Desa Anggoli untuk memanfaatkan daerah aliran sungai yang ada di desa dengan manfaat mengembangkan kemampuan masyarakat dalam melindungi daerah aliran sungai dengan baik dalam meningkatkan pembanguan desa, dan meningkatkan kesehejateraan masyarakat desa.

kearifan lokal yang harus dikembangkan, karena memiliki nilai yang positif dan banyak manfaatnya. Aturan lubuk larangan mengartikan sebuah lubuk bagian sungai yang berceruk dan menjadi tempat ikan bertelur, dilarang dan dibatasi pengambilan ikannya selama kurun waktu tertentu, atas dasar kesepakatan bersama masyarakat. 
Dalam penetapan penanganan pengurus lubuk larangan Sepakat di limpahkan Pemerintah Desa dan masyarakat dari hasil musyawarah desa pada tanggal 15 Februari 2015 bertempat di Balai Desa Anggoli Kecamatan Sibabangun Kabupaten Tapanuli Tengah yang di tunjuk selaku Ketua pengurus lubuk larangan Sepakat pimpinan unit usaha pemanfaatan serta penanganan hasil lubuk larangan Sepakat sebagai berikut:

\section{Ketua : Mian Supardi \\ Sekretaris : Ismail Ginting \\ Bendahara : Yayuk}

Anggota Unit Usaha pemanfaatan lubuk larangan Sepakat serta penanganan hasil lubuk larangan dan menjaga lubuk larangan Sepakat sebagai berikut:

Di bagian hulu yaitu sungai bagian atas yang bertugas dalam penjagaan lubuk larangan sebagai berikut:

1) Hardian Sianturi

2) Ahmadi Daulay

3) Timbul Simbolon

4) Maulida Napitupulu

5) Sabda Tarihoran

Di bagian hilir yaitu sungai yang berada dibawah atau biasa disebut dengan daerah tempat berakhirnya sebuah aliran sungai yang bertugas dalam penjagaan lubuk larangan sebagai berikut:

1) Ismail Ginting

2) Payungan Napitupulu

3) Pirgo Simbolon

4) Erniwati Nasution

5) Ida Napitulu

\section{Pengujian Persyaratan Analisis}

Uji coba instrument dilakukann untuk mengetahui validasi dan reliabilitas instrument sehingga instrument (angket) dapat digunakan untuk pengumpulan data. Uju coba instrument yang berupa angket diujikan 72 responden. Sebagai pengujian persyaratan analisis penulis menggunakan sebagai berikut:

1. Uji Validitas

Uji validitas angket menggunakan analisi butir dengan menggunakan rumus kolerasi Product Moment. Hasil analisi uji validasi dikonsultasikan dengan nilai signifikan $5 \%$ dan $r_{\text {hitung }}$ harus lebih besar $r_{\text {tabel. }}$

2. Uji Signifikansi (Uji T)
Uji signifikansi kolerasi Product Moment digunakan untuk mengukur kedua variabel penelitian signifikan atau tidak dengan melalui perhitungan uji t dengan menggunakan $\mathrm{dk}=\mathrm{n}-2$ dan nilai taraf kesalahannya yaitu $5 \%$.

3. Uji Determinasi

Uji determinasi dilakukan sebagai pengukuran untuk melihat besaran variabel $X$ dengan variabel $Y$ dengan mengkuadratkan nilai $r_{\text {hitung }}$ kemudian dikalikan $100 \%$.

\section{Jenis Penelitian}

Adapun jenis penelitian yang digunakan penulis pada penelitian ini adalah metode dengan analisa data kuantitatif. Sugiyono mendefenisikan bahwa: "Data kuantitatif adalah data yang berbentuk angka atau data kualitatif yang diangkakan".(Sugiyono, "Metode Penelitian Administrasi" (Bandung: Alfabeta, 2011)

Kemudian dianalisis secara berurutan untuk menemukan gejala yang dihubungkan dengan pemecahan masalah baik dari sudut pandang teoritis maupun praktis.

\section{Defenisi Konsep dan Operasioanal Defenisi Konsep}

Konsep merupakan suatu istilah untuk menggambarkan kejadian. Singarimbun mendefenisikan bahwa:Konsep adalah istilah atau defenisi yang digunakan untuk menggambarkan secara abstrak kejadian, keadaan, kelompok atau individu yang menjadi pusat perhatian ilmu sosial. Untuk itu ada beberapa konsep yang akan diangkat dalam penelitian ini adalah sebagai berikut:

1) Pemanfaatan adalah upaya pendayagunaan suatu hal baik berupa materi maupun non material.

2) Lubuk larangan adalah sungai yang dikelola dan dimanfaatkan oleh masyarakat untuk melestarikan sumber daya alam yaitu salah satunya sungai yang terdapat di wilayah tertentu seperti sebuah desa dalam kesepakatan bersama dan manfaatnya untuk kepentingan bersama dalam bermasyarakat.

3) Kesehjateraan adalah kondisi manusia dalam keadaan makmur,keadaan sehat, 
damai dalam memperbaiki kehidupan masyarakat.

4) Sosial adalah sesuatu yang dapat dicapai atau yang dihasilkan sekelompok manusia dengan secara individu yang terlibat aktivitas dan kegiatan secara bersama sama.

5) Masyarakat adalah suatu sistem dari kebiasaan dan tata cara, dari wewenang dan kerja sama antara berbagai kelompok dan penggolongan, dari pengawasan tingkah laku serta kebebasan-kebebasan manusia.

6) Kesehjateraan masyarakat adalah suatu keadaan hidup yang terpenuhinya kebutuhan fisik dan mental atau kebutuhan sendiri tetapi juga terpenuhinya kebutuhan masyarakat.

7) Taraf hidup masyarakat dan kesehjateraan adalah hubungan timbal balik yang sangat erat dalam meningkatkan suatu usaha yang dimiliki desa untuk menikmati hasil yang memuaskan dari pendapatan desa tersebut.

\section{Defenisi Operasional}

Defenisi operasioanal merupakan unsur penelitian yang memberitahukan bagaimana caranya mengukur suatu variabel penelitian sehingga dengan pengukuran ini dapat diketahui indikator apa saja pendukung untuk analisa dalam variabel tersebut. Untuk pemberitahuan arah yang lebih jelas dari penelitian ini, maka penulis membuat defenisi operasional dengan menggunakan dua variabel yaitu Bebas $(X)$ dan $(Y)$

1) Variabel bebas (variabel $X$ ), pemanfaatan lubuk larangan.

Indikator variabel $X$ adalah:

Indikator

a. Sungai

b. Lingkungan

c. Hasil

2) Variabel terikat (variabel $Y$ ), meningkatkan masyarakat.

Indikator variabel $Y$ adalah:
a. Taraf hidup
b. Meningkatkan perekonomian desa
c. Meningkatkan pendapatan asli desa
d. Pengelolaan potensi desa

\section{Teknik dan Alat Pengumpulan Data}

Teknik pengumpulan data yang di pakai dalam penelitian ini adalah sebagai berikut:

1. Pengumpulan data primer (primary) yaitu data yang diperoleh melalui kegiatan penelitian langsung terjun ke lokasi penelitian untuk mencari data yang lengkap dan berkaitan dengan masalah yang diteliti. penelitian ini akan dilakukan dengan cara sebagai berikut:

1) Observasi adalah penelitian yang dilakukan secara langsung permasalahan yang diteliti secara langsung

2) Angket yaitu pengumpulan data dengan membuat daftar pertanyaan dan sudah disiapkan jawabannya, hanya memilih sesuai pilihannya.

3) Studi dokumentasi, yaitu mengumpulkan serta mempelajari data-data yang berhubungan dengan masalah yang dibahas. Baik dalam bentuk peraturan perundangundangan, buku literature, majalah, Koran dan sumber lain yang dapat dijadikan sebagai bahan kerangka teori dalam memperkaya pembahasan dalam penelitian ini.

2. Pengumpulan data secara sekunder (secondary data) yaitu dengan mempelajari dan menelaah buku, majalah, tulisan, karangan ilmiah maupun informasi-informasi yang ada relevansinya dan sesuai dengan masalah yang diteliti. hal ini dilakukan melalui studi pustaka yang membantu menemukaan teori-teori yang mendukung penelitian.

\section{Teknik Analisis Data}

Data berasal dari hasil penelitian dengan menggunakan angket dan studi dokumentasi kemudian dianalisis menggunakan statistik yaitu hasil jawaban responden. Selanjutnya, data dianalisis dengan menggunakan uji skoring, yaitu setiap jawaban diberi nilai skor sebagai berikut:
a. Sangat setuju
diberi skor 4
b. Setuju
c. Kurang setuju
diberi skor 3
d. Tidak setuju 


\section{Teknik Pengujian Hipotesis}

Kemudian untuk melihat jawaban gradasi yang positif sampai yang negatif, analisis dengan menggunakan rumus korelasi product moment yaitu:

$$
\mathrm{r}_{\mathrm{Xy}}=\frac{N \sum X Y-\left(\sum X\right)\left(\sum Y\right)}{\sqrt{\left\{N \sum X^{2}-(\Sigma X)^{2}\right\}\left\{N \sum Y^{2}-(\Sigma Y)^{2}\right\}}}
$$

Keterangan:

$r_{x y}=$ Koefisien Korelasi antara Variabel $X$ dan $Y$

$\mathrm{N}=$ Jumlah Sampel

$\Sigma_{\mathrm{x}}=$ Jumlah Skor Variabel $\mathrm{X}$

$\Sigma_{y}=$ Jumlah Skor Variabel $Y$

$\Sigma_{\mathrm{x}}^{2}=$ Jumlah Kuadrat Variabel $\mathrm{X}$

$\Sigma_{y}^{2}=$ Jumlah Kuadrat Variabel $Y$

$\Sigma x_{y}=$ Jumlah Skor Variabel $X$ Kali Skor Variabel Y"

Selanjutnya untuk menguji hipotesis penelitian di $\mathbf{j} \mathrm{ji}$ dergan keberartian korelasi dengar merggur:akan statistik $t$ ( $u j i ~ t)$ dengan menjguriakan rumus:

Keterangan:

$$
t=\frac{r \sqrt{n-2}}{v \overline{1}=\overline{r^{2}}}
$$

$\mathrm{t}=\mathrm{t}_{\text {hitung }}$

$\mathrm{n}=$ jumlah sampel

$r=$ nilai korelasi

Selanjutnya dihitung komulatifnya dan pada akhirnya dihitung rata-rata persentasenya.

Koefisien yang ditentukan, dengan rumus:

Keterangan:

$$
\mathrm{D}=r_{x y^{2}} \times 100 \%
$$

$\mathrm{D}=$ koefisien determinasi

$r_{x y^{2}}=$ pengkuadratan nilai $r$ hitung

\section{PEMBAHASAN}

Dengan adanya program lubuk larangan Sepakat melalui BUMDes ini kebersamaan masyarakat dalam mengurus lubuk larangan Sepakat sangat antusias sebab lubuk larangan Sepakat merupakan sumber pendapatan asli desa, selanjutnya perairan sungai Desa Anggoli mulai terjaga dan taraf hidup masyarakat mulai terbantu dengan hasil panen dari lubuk larangan Sepakat, khususnya untuk membantu sandang dan pangan bagi anak yatim piatu dan orang tua jompo.

Berdasarkan data yang diperoleh dari penelitian ini angket disebarkan kepada 72 sampel 10 pertanyaan seperti yang tertera dalam tabel dibawah ini.

Variabel Bebas ( X )

Jawaban Responden Terhadap Pemanfaatan Daerah Aliran Sungai Dengan Dibuatnya Lubuk Larangan Sepakat?

\begin{tabular}{|c|l|c|c|}
\hline No & \multicolumn{1}{|c|}{ Jawaban } & Frekuensi & $\begin{array}{c}\text { Presentase } \\
(\%)\end{array}$ \\
\hline 1 & Sangat setuju & 60 & 83,33 \\
\hline 2 & Setuju & 12 & 16,66 \\
\hline 3 & Kurang setuju & - & - \\
\hline 4 & Tidak setuju & - & - \\
\hline \multicolumn{2}{|c|}{ Jumlah } & - & $100 \%$ \\
\hline
\end{tabular}

Dari hasil jawaban yang diperoleh dari responden dapat disimpulkan bahwa masyarakat sangat setuju dengan keberadaan lubuk larangan Sepakat dalam hal pemanfaatan daerah aliran sungai dengan demikian masyarakat ataupun pengunjung sudah mengetahui aturan untuk saling menjaga daerah aliran sungai jika ingin melihat lubuk larangan.

Jawaban Responden Terhadap Manfaat Yang Diperoleh Setelah Berjalannya Pengelolaan Daerah Aliran Sungai Dengan Adanya Lubuk Larangan Sepakat Menjadi Lebih Baik?

\begin{tabular}{|c|l|c|c|}
\hline No & \multicolumn{1}{|c|}{ Jawaban } & Frekuensi & $\begin{array}{c}\text { Presentase } \\
(\%)\end{array}$ \\
\hline 1 & Sangat Setuju & 54 & 75 \\
\hline 2 & Setuju & 13 & 18,05 \\
\hline 3 & Kurang setuju & 4 & 5,55 \\
\hline 4 & Tidak Setuju & 1 & 1,38 \\
\hline \multicolumn{2}{|c|}{ Jumlah } & 72 & $100 \%$ \\
\hline
\end{tabular}

Dari hasil jawaban yang diperoleh dari sejumlah responden dapat disimpulkan bahwa masyarakat sangat setuju dengan manfaat yang diperoleh setelah berjalannya pengelolaan daerah aliran sungai dengan adanya lubuk larangan Sepakat menjadi lebih bermanfaat.

Jawaban Responden Terhadap Adanya Lubuk Larangan Sepakat Daerah Aliran Sungai Terjaga Ekosistemnya? 


\begin{tabular}{|c|l|c|c|}
\hline No & \multicolumn{1}{|c|}{ Jawaban } & Frekuensi & $\begin{array}{c}\text { Presentase } \\
(\%)\end{array}$ \\
\hline 1 & Sangat Setuju & 59 & 81,94 \\
\hline 2 & Setuju & 9 & 12,5 \\
\hline 3 & Kurang setuju & 4 & 5,55 \\
\hline 4 & Tidak Setuju & - & - \\
\hline \multicolumn{2}{|c|}{ Jumlah } & 72 & $100 \%$ \\
\hline
\end{tabular}

Dari hasil jawaban yang diperoleh dari sejumlah responden dapat disimpulkan bahwa masyarakat sangat setuju dengan adanya lubuk larangan Sepakat daerah aliran sungai menjadi terjaga ekosistem ikan, hewan dan tumbuhan yang berada di sungai.

Jawaban Responden Terhadap

Setelah Adanya Pemanfaatan Lubuk Larangan Sepakat Kerja Sama Masyarakat Untuk Menjaga Lingkungan Sungai Semakin Baik?

\begin{tabular}{|c|l|c|c|}
\hline No & \multicolumn{1}{|c|}{ Jawaban } & Frekuensi & $\begin{array}{c}\text { Presentase } \\
(\%)\end{array}$ \\
\hline 1 & Sangat Setuju & 51 & 70,83 \\
\hline 2 & Setuju & 17 & 23,61 \\
\hline 3 & Kurang setuju & 3 & 4,16 \\
\hline 4 & Tidak Setuju & 1 & 1,38 \\
\hline \multicolumn{2}{|c|}{ Jumlah } & 72 & $100 \%$ \\
\hline
\end{tabular}

Dari hasil jawaban yang diperoleh dari sejumlah responden dapat disimpulkan bahwa masyarakat sangat setuju menjalin kerja sama untuk menjaga lingkungan sungai menjadi lebih baik di karenakan masyarakat tau bahwa daerah aliran sungai sangat penting untuk kepentingan masyarakat sehari-hari.

Jawaban Responden Terhadap

Pemanfaatan Daerah Lingkungan Lubuk Larangan Sepakat Terjaga Dengan Baik Oleh Masyarakat?

\begin{tabular}{|c|l|c|c|}
\hline No & \multicolumn{1}{|c|}{ Jawaban } & Frekuensi & $\begin{array}{c}\text { Presentase } \\
(\%)\end{array}$ \\
\hline 1 & Sangat Setuju & 53 & 73,61 \\
\hline 2 & Setuju & 16 & 22,22 \\
\hline 3 & Kurang setuju & 3 & 4,16 \\
\hline 4 & Tidak Setuju & - & - \\
\hline \multicolumn{2}{|c|}{ Jumlah } & 72 & $100 \%$ \\
\hline
\end{tabular}

Dari hasil jawaban yang diperoleh dari sejumlah responden dapat disimpulkan bahwa masyarakat sangat antusias dengan adanya pemanfaatan lubuk larangan Sepakat sehingga lubuk larangan yang berada di Desa Anggoli terjaga dengan baik.

Jawaban Responden Terhadap Apakah Setelah Dibukanya Lubuk Larangan Sepakat Kembali Dikelolah Oleh BUMDes?

\begin{tabular}{|c|l|c|c|}
\hline No & \multicolumn{1}{|c|}{ Jawaban } & Frekuensi & $\begin{array}{c}\text { Presentase } \\
(\%)\end{array}$ \\
\hline 1 & Sangat Setuju & 49 & 68,27 \\
\hline 2 & Setuju & 17 & 23,61 \\
\hline 3 & Kurang setuju & 6 & 8,33 \\
\hline 4 & Tidak Setuju & - & - \\
\hline & Jumlah & 72 & $100 \%$ \\
\hline
\end{tabular}

Dari hasil jawaban yang diperoleh dari sejumlah responden dapat disimpulkan bahwa masyarakat menjawab kebanyakan sangat setuju lubuk larangan Sepakat di kelolah kembali oleh BUMDes.

Jawaban Responden Terhadap Pembagian Hasil Panen Lubuk Larangan Sepakat Merata Pembagiannya Kepada Anak Yatim Piatu Orang Tua Jompo Dan Pembangunan desa?

\begin{tabular}{|c|l|c|c|}
\hline No & \multicolumn{1}{|c|}{ Jawaban } & Frekuensi & $\begin{array}{c}\text { Presentase } \\
(\%)\end{array}$ \\
\hline 1 & Sangat Setuju & 51 & 70,83 \\
\hline 2 & Setuju & 9 & 12,5 \\
\hline 3 & Kurang setuju & 9 & 12,5 \\
\hline 4 & Tidak Setuju & 3 & 4,16 \\
\hline \multicolumn{2}{|c|}{ Jumlah } & 72 & $100 \%$ \\
\hline
\end{tabular}

Dari hasil jawaban yang diperoleh dari sejumlah responden dapat disimpulkan bahwa masyarakat sangat setuju dengan melihat langsung hasil panen lubuk larangan Sepakat merata pembagiannya kepada seluruh anak yatim piatu dan orang tua jompo.

Jawaban Responden Terhadap Pembagian Hasil Panen Yang Diperoleh Dapat Bermanfaat Bagi Masyarakat? 


\begin{tabular}{|c|l|c|c|}
\hline No & \multicolumn{1}{|c|}{ Jawaban } & Frekuensi & $\begin{array}{c}\text { Presentase } \\
(\%)\end{array}$ \\
\hline 1 & Sangat Setuju & 47 & 65,27 \\
\hline 2 & Setuju & 18 & 25 \\
\hline 3 & Kurang setuju & 2 & 2,77 \\
\hline 4 & Tidak Setuju & 5 & 6,94 \\
\hline \multicolumn{2}{|c|}{ Jumlah } & 72 & $100 \%$ \\
\hline
\end{tabular}

Dari hasil jawaban yang diperoleh dari sejumlah responden dapat disimpulkan bahwa masyarakat sangat setuju pembagian hasil panen lubuk larangan Sepakat bermanfaat bagi masyarakat untuk membangun sarana dan prasarana desa, pengadaan alat serikat tolong menolong (STM) dibidang kematian dan pernikahan.

Jawaban Responden Terhadap Hasil Lubuk Larangan Sepakat Taraf Hidup Masyarakat Untuk Anak Yatim Piatu Dan Orang Tua Jompo Terbantu?

\begin{tabular}{|c|l|c|c|}
\hline No & \multicolumn{1}{|c|}{ Jawaban } & Frekuensi & $\begin{array}{c}\text { Presentase } \\
(\%)\end{array}$ \\
\hline 1 & Sangat Setuju & 42 & 58,33 \\
\hline 2 & Setuju & 20 & 27,77 \\
\hline 3 & Kurang setuju & 7 & 9,72 \\
\hline 4 & Tidak Setuju & 3 & 4,16 \\
\hline \multicolumn{2}{|c|}{ Jumlah } & 72 & $100 \%$ \\
\hline
\end{tabular}

Dari hasil jawaban yang diperoleh dari sejumlah responden dapat disimpulkan bahwa masyarakat sangat setuju dengan hasil lubuk larangan sepakat taraf hidup masyarakat untuk anak yatim piatu dan orang tua jompo terbantu dengan baik dan berguna untuk kebutuhan yang diperlukan.

Jawaban Responden Terhadap Hasil Panen Lubuk Larangan Sepakat di Kelolah Kembali Oleh BUMDes Untuk Pembelian Bibit Ikan?

\begin{tabular}{|c|l|c|c|}
\hline No & \multicolumn{1}{|c|}{ Jawaban } & Frekuensi & $\begin{array}{c}\text { Presentase } \\
(\%)\end{array}$ \\
\hline 1 & Sangat Setuju & 44 & 61,11 \\
\hline 2 & Setuju & 17 & 23,61 \\
\hline 3 & Kurang setuju & 7 & 9,72 \\
\hline 4 & Tidak Setuju & 4 & 5,55 \\
\hline \multicolumn{2}{|c|}{ Jumlah } & 72 & $100 \%$ \\
\hline
\end{tabular}

Dari hasil jawaban yang diperoleh dari sejumlah responden dapat disimpulkan bahwa masyarakat menjawab sangat setuju berarti masyarakat mendukung dari hasil panen lubuk larangan Sepakat di kelolah kembali oleh BUMDes untuk pembelian bibit ikan. Intinya masyarakat percaya dengan pengelolaan lubuk larangan yang dikelolah oleh BUMDes menjadi berkelanjutan.

Berdasarkan hasil tersebut diperoleh interval tertinggi yaitu 38 - 40 sebanyak 25 termasuk kategori sangat setuju. Maka dapat disimpulkan bahwa pemanfaatan lubuk larangan Sepakat termasuk kategori jawaban sangat setuju.

\section{Variabel Terikat ( $Y$ )}

Jawaban Responden Terhadap Apakah Pemanfaatan Lubuk Larangan Sepakat Meningkatkan Kesehjateraan Taraf Hidup Masyarakat?

\begin{tabular}{|c|l|c|c|}
\hline No & \multicolumn{1}{|c|}{ Jawaban } & Frekuensi & $\begin{array}{c}\text { Presentase } \\
(\%)\end{array}$ \\
\hline 1 & Sangat Setuju & 38 & 52,77 \\
\hline 2 & Setuju & 27 & 37,5 \\
\hline 3 & Kurang setuju & 4 & 5,55 \\
\hline 4 & Tidak Setuju & 3 & 4,16 \\
\hline \multicolumn{2}{|c|}{ Jumlah } & 72 & $100 \%$ \\
\hline
\end{tabular}

Dari hasil jawaban yang diperoleh dari sejumlah responden dapat disimpulkan bahwa masyarakat sangat setuju dengan adanya pemanfaatan lubuk larangan Sepakat yang mampu meningkatkan kesehjateraan taraf hidup masyarakat.

Jawaban Responden Terhadap Apakah Menurut Anda Dengan Adanya Pemanfaatan Lubuk Larangan Sepakat Meningkatkan Taraf Hidup Anak Yatim dan Orang Tua Jompo Terbantu?

\begin{tabular}{|c|l|c|c|}
\hline No & \multicolumn{1}{|c|}{ Jawaban } & Frekuensi & $\begin{array}{c}\text { Presentase } \\
(\%)\end{array}$ \\
\hline 1 & Sangat Setuju & 37 & 51,38 \\
\hline 2 & Setuju & 20 & 27,77 \\
\hline 3 & Kurang setuju & 11 & 15,27 \\
\hline 4 & Tidak Setuju & 4 & 5,55 \\
\hline \multicolumn{2}{|c|}{ Jumlah } & 72 & $100 \%$ \\
\hline
\end{tabular}

Dari hasil jawaba yang diperoleh dari sejumlah responden dapat disimpulkan bahwa masyarakat sangat setuju dengan 
adanya pemanfaatan lubuk larangan Sepakat dapat membantu meningkatkan taraf hidup anak yatim piatu dan orang tua jompo terbantu.

Jawaban Responden Terhadap Apakah Dengan Adanya Hasil Pembukaan Lubuk Larangan Sepakat Dapat Meningkatkan Perekonomian De

\begin{tabular}{|c|l|c|c|}
\hline No & \multicolumn{1}{|c|}{ Jawaban } & Frekuensi & $\begin{array}{c}\text { Presentase } \\
(\%)\end{array}$ \\
\hline 1 & Sangat Setuju & 37 & 51,38 \\
\hline 2 & Setuju & 27 & 37,5 \\
\hline 3 & Kurang setuju & 4 & 5,55 \\
\hline 4 & Tidak Setuju & 4 & 5,55 \\
\hline \multicolumn{2}{|c|}{ Jumlah } & $72 \%$ & $100 \%$ \\
\hline
\end{tabular}

Dari hasil jawaban yang diperoleh dari sejumlah responden dapat disimpulkan bahwa masyarakat sangat setuju dengan adanya hasil pembukaan lubuk larangan Sepakat mampu meningkatkan perekonomian desa menjadi lebih baik. Jawaban Responden Terhadap

Bagaimana Harapan Masyarakat Kedepannya Untuk Meningkatkan Perekonomian Desa Dengan Adanya Lubuk Larangan Sepakat Masih Berkelanjutan di Kelolah Kembali?

\begin{tabular}{|c|l|c|c|}
\hline No & \multicolumn{1}{|c|}{ Jawaban } & Frekuensi & $\begin{array}{c}\text { Presentase } \\
(\%)\end{array}$ \\
\hline 1 & Sangat Setuju & 40 & 55,55 \\
\hline 2 & Setuju & 23 & 31,94 \\
\hline 3 & Kurang setuju & 6 & 8,33 \\
\hline 4 & Tidak Setuju & 3 & 4,16 \\
\hline \multicolumn{2}{|c|}{ Jumlah } & 72 & $100 \%$ \\
\hline
\end{tabular}

Dari hasil jawaban yang diperoleh dari sejumlah responden dapat disimpulkan bahwa masyarakat sangat setuju harapan masyarakat desa untuk meningkatkan perekonomian desa masih berkelanjutan dengan di kelolahnya kembali lubuk larangan tersebut.

Jawaban Responden Terhadap Apakah Menurut Anda Lubuk Larangan Sepakat Menjadi Salah Satu Sumber Daya Tarik Masyarakat Dari Luar Desa Untuk Meningkatkan Perekonomian Desa?

\begin{tabular}{|c|l|c|c|}
\hline No & Jawaban & Frekuensi & Presentase(\%) \\
\hline 1 & Sangat Setuju & 36 & 50 \\
\hline 2 & Setuju & 26 & 36,11 \\
\hline 3 & Kurang setuju & 8 & 11,11 \\
\hline 4 & Tidak Setuju & 2 & 2,77 \\
\hline \multicolumn{2}{|c|}{ Jumlah } & 72 & $100 \%$ \\
\hline
\end{tabular}

Dari hasil jawaban yang diperoleh dari sejumlah responden dapat disimpulkan bahwa masyarakat sangat setuju setiap pembukaan lubuk larangan Sepakat selalu ada pemberitahuan ke kampung-kampung lain, justru ini menjadi salah satu sumber pendapatan dari hasil untuk tambahan uang masuk dalam meningkatkan perekonomian desa.

Jawaban Responden Terhadap Bagaimana Pendapat Anda Dengan Dibentuknya Lubuk Larangan Sepakat Dapat Meningkatkan Pendapatan Asli Desa?

\begin{tabular}{|c|c|c|c|}
\hline No & Jawaban & Frekuensi & Presentase $(\%)$ \\
\hline 1 & $\begin{array}{l}\text { Sangat } \\
\text { Setuju }\end{array}$ & 39 & 54,16 \\
\hline 2 & Setuju & 25 & 34,72 \\
\hline 3 & Kurang setuju & 4 & 5,55 \\
\hline 4 & Tidak Setuju & 4 & 5,55 \\
\hline \multicolumn{2}{|r|}{ Jumlah } & 72 & $100 \%$ \\
\hline
\end{tabular}

Dari hasil jawaban yang diperoleh dari sejumlah responden dapat disimpulkan bahwa masyarakat sangat setuju dengan dibentuknya lubuk larangan Sepakat dapat meningkatkan pendapatan asli desa. Jawaban Responden Terhadap Dengan Pendapatan Asli Desa Semakin Bertambah Jenis Usaha Yang Dijalankan BUMDes Sepakat Yaitu Lubuk Larangan Mampu Memberikan Dampak Positif Kepada Masyarakat?

\begin{tabular}{|c|l|c|c|}
\hline No & Jawaban & Frekuensi & Presentase(\%) \\
\hline 1 & Sangat Setuju & 36 & 50 \\
\hline 2 & Setuju & 23 & 31,94 \\
\hline 3 & Kurang setuju & 8 & 11,11 \\
\hline 4 & Tidak Setuju & 5 & 6,94 \\
\hline \multicolumn{2}{|c|}{ Jumlah } & 72 & $100 \%$ \\
\hline
\end{tabular}


Dari hasil jawaban yang diperoleh dari sejumlah responden dapat disimpulkan bahwa masyarakat sangat setuju dengan pendapatan asli desa semakin bertambah jenis usaha yang dijalankan BUMDes Sepakat mampu memberikan dampak positif kepada masyarakat.

Jawaban Responden Terhadap

Apakah Anda Mengalami Perubahan Setelah Program BUMDes Lubuk Larangan Sepakat Mampu Mengelolah Sumber Daya Alam Sungai Menjadi Sumber Pendapatan Asli Desa?

\begin{tabular}{|c|l|c|c|}
\hline No & \multicolumn{1}{|c|}{ Jawaban } & Frekuensi & $\begin{array}{c}\text { Presentase } \\
(\%)\end{array}$ \\
\hline 1 & Sangat Setuju & 35 & 48,61 \\
\hline 2 & Setuju & 21 & 29,16 \\
\hline 3 & Kurang setuju & 6 & 8,33 \\
\hline 4 & Tidak Setuju & 10 & 13,88 \\
\hline \multicolumn{2}{|c|}{ Jumlah } & 72 & $100 \%$ \\
\hline
\end{tabular}

Dari hasil jawaban yang diperoleh dari sejumlah responden dapat disimpulkan bahwa masyarakat sangat setuju dengan perubahan setelah BUMDes mampu mengelolah sumber daya alam sungai menjadi sumber pendapatan asli desa. Hal ini menjadi sumber pendapat asli desa dari sumber daya alam yang di kelolah oleh masyarakat berhasil di kembangkan dengan baik.

Jawaban Responden Terhadap Apakah Anda Setuju Bahwa BUMDes Lubuk Larangan Sepakat Mampu Mengelolah Potensi Desa?

\begin{tabular}{|c|l|c|c|}
\hline No & \multicolumn{1}{|c|}{ Jawaban } & Frekuensi & $\begin{array}{c}\text { Presentase } \\
(\%)\end{array}$ \\
\hline 1 & Sangat Setuju & 34 & 47,22 \\
\hline 2 & Setuju & 26 & 36,11 \\
\hline 3 & Kurang setuju & 7 & 9,72 \\
\hline 4 & Tidak Setuju & 5 & 6,94 \\
\hline \multicolumn{2}{|c|}{ Jumlah } & 72 & $100 \%$ \\
\hline
\end{tabular}

Dari hasil jawaban yang diperoleh dari sejumlah responden dapat disimpulkan bahwa masyarakat sangat setuju dengan BUMDes lubuk larangan Sepakat yang mampu mengelolah potensi desa.
Jawaban Responden Terhadap Apakah Anda Setuju Bahwa Pengelolaan Potensi Desa Sudah Sangat Optimal Untuk Meningkatkan Kesehjateraan Taraf Hidup Masyarakat?

\begin{tabular}{|c|l|c|c|}
\hline No & \multicolumn{1}{|c|}{ Jawaban } & Frekuensi & $\begin{array}{c}\text { Presentase } \\
(\%)\end{array}$ \\
\hline 1 & Sangat Setuju & 30 & 41,66 \\
\hline 2 & Setuju & 30 & 41,66 \\
\hline 3 & Kurang setuju & 7 & 9,72 \\
\hline 4 & Tidak Setuju & 5 & 6,94 \\
\hline \multicolumn{2}{|c|}{ Jumlah } & 72 & $100 \%$ \\
\hline
\end{tabular}

Dari hasil jawaban yang diperoleh dari sejumlah responden dapat disimpulkan bahwa masyarakat menerima dan sangat mendukung pengelolaan potensi desa sudah sangat optimal pengelolaannya untuk meningkatkan kesehjateraan taraf hidup masyarakat.

Berdasarkan hasil tersebut diperoleh interval tertinggi yaitu 32 - 35 sebanyak 31 termasuk kategori setuju. Maka dapat disimpulkan bahwa lubuk larangan dapat meningkatkan kesehjateraan masyarakat di Desa Anggoli termasuk kategori setuju.

\section{Uji Hipotesis}

Hipotesis adalah pengajuan jawaban sementara atas masalah yang terdapat dalam penelitian. Hipotesis yang penulis tetapkan dalam penelitian ini akan dilakukan pengujian untuk membuktikan diterima atau ditolaknya suatu penelitian. Setelah penulis memperoleh data tentang kedua variabel, maka langkah selanjutnya penulis akan melakukan analisis data tersebut untuk menguji hipotesis.

Untuk melakukan pengujian hipotesis dalam penelitian ini, peneliti menggunakan teknik knleras PlOdıCt Mnment yaitu:

$r_{\mathrm{xy}}=\frac{N \sum X Y-\left(\sum X\right)(\Sigma Y)}{\sqrt{\left\{N \Sigma X^{2}-\left(\sum X\right)^{2}\right\}\left\{N \Sigma Y^{2}-\left(\sum Y\right)^{2}\right\}}}$

Keterangan:

$r_{x y}=$ Koefisien Korelasi antara Variabel $X$ dan $Y$

$\mathrm{N}=$ Jumlah Sampel

$\Sigma_{x}=$ Jumlah Skor Variabel $X$

$\Sigma_{y}=$ Jumlah Skor Variabel $Y$ 
$\Sigma_{x}^{2}=$ Jumlah Kuadrat Variabel $X$

$\Sigma_{y}^{2}=$ Jumlah Kuadrat Variabel $Y$

$\Sigma x_{y}=$ Jumlah Skor Variabel $\mathrm{X}$ Kali Skor Variabel $Y$

Untuk memperoleh harga indeks korelasi product moment $r_{x y}$ dari tabel hasil hitung rekapitulasi yaitu :

Nilai $\mathrm{N}=72$

$\begin{array}{ll}\sum X & =2589 \\ \sum Y & =2364 \\ \sum X^{2} & =93701 \\ \sum Y^{2} & =78306 \\ \sum X Y & =85019\end{array}$

Dengan mendistribusikan nilai-nilai diatas ke dalam rumus kolerasi product moment diperoleh sebagai berikut:

Selanjutnya nilai-nilai tersebut didistribusikan ke dalam rumus korelasi " $r$ " Product Momeni sehnga danat diperoleh sebagai berikut:

$$
\begin{aligned}
& \mathrm{r}_{\mathrm{xy}}=\frac{N \Sigma X Y-(\Sigma X)(\Sigma Y)}{\sqrt{\left[N \Sigma X^{2}-(\Sigma S)^{2}\right\}\left(N \Sigma Y^{2}-(\Sigma V)^{23}\right.}}= \\
& \mathrm{r}_{\mathrm{xy}} \\
& 72.85) 19-(2580)(2364)
\end{aligned}
$$

$\sqrt{\left\{72.93701-(2589)^{2}\right\}\left\{72.88306-(2364)^{2}\right\}}$

$\mathrm{T}_{x y}=\frac{61212-61203}{\sqrt{\left(6746^{2}-6702\right)}}$

$r_{x y}=\frac{10}{\sqrt{\{4} \frac{10}{35\}\{496\}}}$

$r_{x y}=-\frac{10}{\sqrt{215}}$

$$
r_{x y}=\frac{10}{14,6}
$$$$
r_{x y}=0,684
$$

Kemudian untuk menguji apakah hipotesis diterima atau ditolak kebenarannya maka dilakukan dengan membandingkan korelasi hasil perhitungan dengan korelasi dalam tabel korelasi.

Sebagaimana telah dikemukakan diatas bahwa hipotesis diterima apabila nilai korelasi hasil perhitungan lebih besar atau sama dengan nilai korelasi dalam tabel korelasi. Dari hasil perhitungan diatas, maka diperoleh nilai-nilai korelasi sebesar 0,684 sedangkan nilai korelasi dalam tabel korelasi $\mathrm{N}=72$ dan taraf signifikansi $5 \%$ diperoleh nilai sebesar 0,235 Berarti nilai $r_{\text {hitung }}>r_{\text {tabel }}$ yaitu $0,684>0,235$. Dengan demikian berarti $(\mathrm{Ha})$ diterima dan $(\mathrm{Ho})$ ditolak. Maka hipotesis dalam penelitian ini yang berbunyi Pemanfaatan Lubuk Larangan untuk Meningkatkan Kesehjateraan Masayarakat di Desa
Anggoli Kecamatan Sibabangun Kabupaten Tapanuli Tengah di terima.

\section{Koefisien Uji Signifikan}

Untuk menguji signifikan yaitu apakah hubungan yang ditemukan itu berlaku untuk seluruh populasi yang berjumlah 72 kepala kelurga, maka perlu di uji signifikansinya. Rumus uj signifikansi kolerasi product moment dapat di hitung dengan cara uji $t$ sebagai berikut:

$t=\frac{-\sqrt{n-2}}{\sqrt{1-r 2}}$

$t=\frac{0,684 \sqrt{72-2}}{\sqrt{1-0,684^{2}}}$

$t=-\frac{0,684 \sqrt{70}}{\sqrt{1-0,4678}}$

$t=\frac{(0,684)(83,66)}{0,532}$

$t=\frac{5,722}{0,532}$

$t=10,75$

Dengan demikian harga $t_{\text {hitung }}$ $=10,75$ dibandingkan dengan harga $t_{\text {tabel }}$ dengan menggunakan taraf kesalahan 5\% dengan $\mathrm{dk}=72-2=70$ maka dapat ditemukan pada nilai-nilai distribısi $t$ yaitu $t_{\text {tabel }}=1,671$

Berdasarkan $t_{\text {hitung }}$ dengar membandingkan harga $t_{\text {tabel }}$, make hipotesis penelitian ini diterima kebenarannya. Kesimpulannya, koefisien korelasi antara pemanfaatan lubuk larangan untuk meningkatkan kesehjahteraan masyarakat di Desa Anggoli Kecamatan Sibabangun Kabupaten Tapanuli Tengah sebesar 0,684 adalah signifikan, artinya koefisien tersebut dapat digeneralisasikan atau dapat berlaku pada populasi dimana sampel yang diambil 72 Kepala Keluarga.

Untuk melihat pemanfaatan lubuk larangan dengan meningkatkan kesehjateraan masyarakat maka dapat dilihat tabel 4.32 yaitu interprestasi koefesien korelasi sebagai berikut:

Tabel Interprestasi Koefesien Korelasi

\begin{tabular}{|c|c|}
\hline Interval Koefesien & Tingkat Hubungan \\
\hline $0,00-0,199$ & Sangat Rendah \\
\hline $0,20-0,399$ & Rendah \\
\hline $0,40-0,599$ & Sedang \\
\hline
\end{tabular}




\begin{tabular}{|c|c|}
\hline $0,60-0,79$ & Kuat \\
\hline $0,80-1,00$ & Sangat kuat \\
\hline
\end{tabular}

Berdasarkan hasil perhitungan maka diperoleh interprestasi koefisien korelasi kuat yaitu berada diantara 0,60 sampai 0,79

Kemudian untuk melihat tingkat presentase pemanfaatan lubuk larangan terhadap meningkatkan kesehjateraan masyarat dapat dihitung dengan rumus:

$D=r x y^{2} x 100 \%$

$\mathrm{D}=0,684^{2} \times 100 \%$

$\mathrm{D}=46,78 \%$

Berdasarkan hasil yang diperoleh perhitungan presentase sebesar $46,78 \%$, pemanfaatan lubuk larangan yang mempengaruhi meningkatkan kesehjateraan masyarakat $46,78 \%$ dengan demikian ada faktor lain yang tidak diteliti hanya sebesar $53,22 \%$.

\section{KESIMPULAN DAN SARAN Simpulan}

Berdasarkan hasil penelitian yang telah diuraikan pada bagian terdahulu, maka dapat ditarik kesimpulan sebagai berikut:

1. Pemanfaatan lubuk larangan Sepakat di Desa Anggoli, dikelolah, diawasi dengan baik dan diperuntuhkan kepada masyarakat yang tidak mampu terkhususnya kepada anak yatim piatu, orang tua jompo sehingga hasil dari pembukaan lubuk larangan bermanfaat untuk memenuhi kebutuhan dengan hasil pembukaan lubuk larangan setiap tahunnya Program ini dijalankan dengan tepat sasaran karena minat masyarakat untuk saling menjaga lubuk larangan sangat baik, selain itu masyarakat sangat mendukung dengan adanya lubuk larangan karena banyak manfaat yang diperoleh untuk kebutuhan masyarakat setempat.

2. Tingkat kesehjateraan masyarakat dalam meningkatkan taraf hidup masyarakat melalui lubuk larangan mengalami peningkatan. Hal ini dapat dilihat semakin bertambahnya penghasilan kepada anak yatim, orang tua jompo, dimana pengurus-pengurus lubuk larangan telah berhasil mengelolah sumber daya alam yaitu sungai dengan baik dan pembagian hasil dengan tepat sasaran,sehingga untuk lebih meningkatkan taraf hidup masyarakt pengurus-pengurus lubuk larangan memperluas daerah lubuk larangan supaya seluruh masyarakat lebih menikmati hasil dari pengelolaan sumber daya alam desa dengan pengadaan lubuk larangan.

3. Pengaruh pemanfaatan lubuk larangan Sepakat untuk meningkatkan kesehjateraan masyarakat di Desa Anggoli Kecamatan Sibabangun Kabupaten Tapanuli Tengah dapat dikatakan baik karena diketahui dari hasil perhitungan uji kolerasi product moment maka diperoleh nilai kolerasi sebesar 0,684 , sedangkan nilai kolerasi dalam tabel kolerasi untuk $\mathrm{N}=72$ dan taraf signifikan 5\% diperoleh nilai sebesar 0,235 berarti nilai rhitung yaitu 0,684 lebih besar dari nilai rtabel yaitu 0,235 dari nilai berarti kolerasi antara variabel $X$ dan variabel $Y$ adalah signifikan. Dengan demikian Hipotesis awal $(\mathrm{Ha})$ diterima dan $(\mathrm{Ho})$ ditolak. Artinya pemanfaatan lubuk larangan untuk meningkatkan kesehjateraan masyarakat khususnya di Desa Anggoli Kecamatan Sibabangun Kabupaten Tapanuli Tengah di terima.

\section{Saran}

1. Diharapkan kepada kepala desa dapat mengawasi pengelolaan hasil lubuk larangan BUMDes Sepakat sehingga pembagian hasil panen bisa lebih optimal sesuai dengan peruntukan penerima.

2. Diharapkan kepada pengurus lubuk larangan BUMDes Sepakat sekiranya memperluas daerah aliran sungai agar hasil yang diperoleh dari panen lubuk larangan Sepakat bertambah sehingga yang menerima akan lebih banyak menerimanya.

3. Untuk masyarakat Desa Anggoli diharapkan dapat menjaga lubuk larangan BUMDes Sepakat, demi untuk kemajuan dan perkembangan desa, serta dapat meningkatkan taraf ekonomi dan kesehjateraan masyarakat dengan cara menjaga pemanfaatan lubuk larangan dengan baik. 


\section{DAFTAR PUSTAKA}

Buku :

Edi, Suharto, 2009, "Membangun Masyarakat Memberdayakan Rakyat Kajian Strategis Pembangunan Kesehjateraan Sosial Dan Pekerjaan Sosial" Bandung: PT Refika Aditama

Mardianto dan Soebianto, 2013, "Pemberdayaan Masyarakat dalam Perspektif Kebijakan Publik" Bandung: Alfabeta

Midgley, 2013, "Kesehjateraan Sosial" Jakarta: PT. Raja Grafindo 2018, "Masalah Sosial Pembangunan Sosial, Pembangunan Sosial dan Kesehjateraan" Yogyakarta: Pustaka Pelajar

Mulder, Niels, 2004, "Individu, Masyarakat, dan Sejarah, Yogyakarta: Kansisus

Poerwadarminta, 2007, Kamus Bahasa Indonesia, Jakarta: Balai Pustaka

Rustanto, Bambang, 2015, "Menangani Kemiskinan" Bandung: PT Remaja Rosdakarya
Soekanto, 2007 , "Pengantar IImu Sosial Sebuah Kajian Pendekatan Struktural" Jakarta: PT Bumi Aksara Sugiyono, "Metode Penelitian Administrasi", Bandung: Alfabeta, 2011

Suharto, Edi, 2005, "Analisis Kebijakan Publik Paduan Praktis Mengkaji Masalah Dan Kebijakan Sosial" Bandung: Alfabeta

Perundang-undangan:

Undang-Undang Dasar Negara Republik Indonesia 1945

Undang-Undang Nomor 6 Tahun 2014 Tentang Desa

Peraturan Pemerintah Republik Indonesia Nomor 38 Tahun 2011 Tentang Sungai

Peraturan Pemerintah Republik Indonesia Nomor 60 Tahun 2014, Tentang Dana Desa Yang Bersumber Dari Anggaran Pendapatan Dan Belanja Negara 